\title{
Cultural hegemony in Charles Dickens's A Tale of Two Cities
}

\section{Meysam Ahmadi}

Department of English Language and Literature, College of Humanities, Boroujerd Branch, Islamic Azad University, Boroujerd, Iran

\author{
Email address:
}

a.meysam27@yahoo.com

\section{To cite this article:}

Meysam Ahmadi. Cultural Hegemony in Charles Dickens's A Tale of Two Cities. International Journal of Literature and Arts. Vol. 2, No. 4, 2014, pp. 98-103. doi: 10.11648/j.ijla.20140204.13

\begin{abstract}
This study delineates the use of cultural hegemony in Charles Dickens's A Tale of Two Cities (1859) through the vantage points of Italian critic Antonio Gramsci (1891-1937) who clarifies domination of the ruling class over ruled class. Cultural hegemony is the mastery of the middle class and governing groups among the lower divisions. Antonio Gramsci declares that the only means of keeping cultural hegemony by super leaders is not the handling of power and coercion; instead, consent, language, use of intellectual men and educational instruments are the ways regarding the implementation of cultural hegemony. In A Tale of Two Cities, Charles Dickens expresses the effects England and France, and manifests the tyrannical events of French Revolution. The beginning of $A$ Tale of Two Cities asserts extreme tyranny and a violation of aristocrats as well as its ending through which the rebels punish sovereigns and the king after the French Revolution. Dickens also shows the ideals of the aristocracy with highlighting the function of cultural hegemony in France and England. Gramsci illustrates that the upper floors by way of indirect control over the mass media, educate their own feelings and values in society because domination is often taken out by means of consent, not compulsion. Ultimately, this research looks for the signs of cultural hegemony, and depicts the alarming events of French Revolution.
\end{abstract}

Keywords: Cultural Hegemony, Consent, Domination, Intellectual Men, Language

\section{Introduction}

The present study concentrates on Dickens's $A$ Tale of Two Cities based on Antonio Gramsci theories, including the presentation of cultural hegemony, domination, consent, and the mapping of language and intellectuality in hegemony. Gramsci's ideologies about cultural hegemony manifest the supremacy of one division over another class of society in which the bourgeoisie imposes their power over lower class and diffuse their ideologies, opinions, and values. Events, such as consent, political domination, and intellectual are broad elements that can be seen in Charles Dickens's A Tale of Two Cities (1859). Gramsci argues:

«The supremacy of social groups expresses itself in three different ways: as domination and as intellectual and moral leadership. A social group dominates antagonistic groups, which it tends to liquidate or to subjugate perhaps even by armed force; it leads kindred and allied groups. A social group can, and indeed must, already exercise leadership before winning governmental power (this one of the principal condition for the winning of such power) It subsequently becomes dominant when it exercises power but even if it holds it firmly in its grasp, it must continue to lead as well» (Fontana 141).

Consent and language are from other main ways of keeping the power and hegemony, by which governors and elite have indirect surveillance over mass media, and consent states the subjugation of ruled class through participate in all the governmental affairs.

In parliamentary law to carry out the methods of cultural hegemony, upper classes do not elaborate coercion or oppression; rather, they use persuasion and conformity. Their instrument to exert practices of cultural hegemony is mass media or even language. For Gramsci, "state is the total complex of practical and theoretical activities with which the ruling class not only justifies and maintain its domination, but manages to win the active consent of those over whom it rules" (1971: 244).

In A Tale of Two Cities, Dickens considers England problems rather than France, and he is more worried about future and what will be happened than about past. Dickens also depicts that the London turmoil is less clear than in bloodshed Paris. Moreover, the novel clarifies the murderous and tyrannical events in London, while are not 
comparable with revolutionary Paris.

Charles Dickens asserts the horrible events. To approve with the research's topic, it is fundamental to analyze and find out the events and signs in Dickens's $A$ Tale of Two Cities, which presents the superiority of aristocrats over the lower level. In this novel, Dickens declares the exertion of power and domination over the mob and individual as an inheritance. The aristocrats also apply the persuasion and leadership as social orders and they train at a distribution of dominant value in church, school, institutions.

\section{Materials and Methods}

Antonio Gramsci elucidates the constitution of people's culture, beliefs, and explanations, by ruling class. Mastery is a great study that cannot be achieved by military unit, but only through news, signs, and the dissemination of symbols and data. In this respect, the instruments of Dickens for showing the domination of England and France are different and he depicts the creation of culture by higher classes without using the military and coercion. In A Tale of Two Cities, Dickens describes the harsh moments for French people at the moment of French Revolution in which fierce and vengeance only culminate bloodshed hearts of freedom fighters.

As Dickens describes in A Tale of Two Cities, there are many signs of rule in the novel, although the lawful instruments such as military, institutions, the army and as easily as the spies search for anyone and anything, are not capable to perform their work successfully, since such lawful organizations are in the favor of the bourgeoisie. The principles and principles are not frail or fragile and compel people to interpret the rules, not through compulsion, merely by imposing their political orientation, culture, and value. Although the Charles's trial in England was mistaken, the French Tribunal is stated as even more horrible, a general background of justice.

According to the critics such as Dominic Strinati, and Antonio Gramsci, who study different aspects of cultural hegemony subjects, including hegemony, and political domination, this report focuses on the concepts of cultural hegemony and its related events. Furthermore, it examines Dickens's ideas to watch just about definitions for the concepts of consent and culture to sustain the hypothesis based on Dickens's own opinion on the cultural hegemony in harmonic frameworks.

By regarding all discussions, supposing that cultural hegemony and constitution of culture occurred in the societies which experience political domination and hegemony. This report aims to consider the subjects such as political domination, consent, and hegemony through an analysis of Dickens's novel, A Tale of Two Cities, and its functions. In other words, cultural hegemony and its effects that affect the spirit of $A$ Tale of Two Cities characters will be hashed out in details.

\section{Findings and Discussions}

Charles Dickens was born on February 7, 1812. In A Tale of Two Cities, he states both the sensations and the darkness of revolution. He is concerned about modern society in all his novels. Dickens is known as a social reformer with a deep feeling for the lower class. His works, which are complicated, dense, and meditative, are also characterized with melodramatic intensity and humor. Many of his titles and aspects are replicated. Charles Dickens was a strong writer for having qualitative works that marked for their depth and social occasion. In spite of his shortfall of a formal education, Daily says, "Dickens revealed in his novels a mastery of English language and a sophisticated depth of thought that have endeared him to many generations of students and readers" (11). Dickens, who addressed social issues and historic events with meditative prospect, is seen as the greatest British author of all times.

At the beginning of novel, Dickens primarily describes the dark and light situation of London and Paris. More to the point, he clarifies that Dr. Alexandre Manette's imprisonment not only had been falsely incarcerated in the Bastille but also he had been left in that location to die. In 1775, Mr. Jarvis Lorry, an official of Tellson's Bank in London infers that her father, Dr. Alexandre Manette, who was lost eighteen years ago, is still alive. On arriving in Paris, they found him in the house of Defarge. The magnet has aged prematurely, and has lost both his memory and his interest. Mr. Lorry and Lucie take her father back to London. With love and passion, Lucie organizes to be attentive of her father back to wellness and awareness.

Five years later, in 1780, a young Frenchman, named Charles Darnay, is sentenced for being a traitor and a spy. All the same, it is Sydney Carton in the courtroom, who shows the similarity between the prisoner and himself to the defense lawyer Mr. Stryver. The jury thus realizes that it could be a pattern of incorrect identity, and Darnay is acquitted. After a few years, and both Darnay and Carton fall in love with Lucie Manette. Lucie gets married with Darnay, who is a French bourgeoisie and repudiated his inheritance and now survives in London under an organized name and works as a teacher. His uncle, the Marquis St. Evremonde, is an infamous man for his over coercion and inflection. The French Revolution breaks out in all its rage with the storming of the Bastille. Darnay secretary returns to Paris to save his faithful servant, Gabelle. Darnay is seized and jailed.

Then, Lucie, her daughter, Dr. Manette, and Mr. Lorry quickly rush to Paris to save Darnay. Madame Defarge, however, seeks personal vengeance against the Evremonde family, for the cruel Marquis had suffered her sister and assassinated her brother. Darnay is re-arrested, attempted, and condemned to destruction. The story ends when Sydney Carton tends to secure Darnay's life by taking his place. The ritual killing is made to complete a promise to Lucie, whom he enjoys. Carton feels noble about his daddy and knows that he will be in the hearts of the Darnays perpetually. 


\section{Cultural Hegemony}

Regarding the ancient time the term cultural hegemony is originally derived from ancient Greek. More to the point, Italian critic Antonio Gramsci bounded the theory of cultural hegemony, and he defines it as, "domination of a culturally diverse society by the ruling class, who manipulate the culture of society, beliefs, explanations, perceptions, and values that the ruling class behaviors become the world view that is imposed and accepted as the cultural norms" (1985: 26). Nineteenth century refers to cultural predomination of one state upon another state, which is a kind of indirect leadership. Bourgeoisie rules lower classes through intimidate to intervention rather than using direct military force that is antagonism and infestation. During the twentieth century, the domination bounded to engage the cultural domination of ruling class in order to fabricate the social symbols of ruled class. The super leaders can predominantly impose their strange viewpoints as usual and inevitable.

Gramsci was interested in cultural domination, which led to research in class and politics. He develops complicated beliefs of class struggle in which the cultural role is significant. If the ruling class begins to destruct, making the opportunity for a lower class to increase its restrictions and create a broad movement capable of battling the norms and getting the hegemony. Nevertheless, if the chance is not taken out, the parallel of forces will shift back to the dominant group, which recreates its hegemony based on a new model of mergers. Cultural hegemony suggests that the fashionable cultural orders of a society are imposed by the ruling group (bourgeois cultural hegemony) should not be understood as normal and inevitable, but must be considered as artificial social principles in governing bodies, nations, exercises, and so on. As Gramsci states, "lower grades are constantly subject to the natural action of higher classes, still when they rebel and rise up: only permanent victory breaks their subordination, and that's not immediately" (1971: 207).

Gramsci viewed that domination is not only coercive, but also symbolic and that all political challenges are challenges of messages, media, and information. Gramsci's insight is that domination can be achieved at the frames of politics, instruction, entertainment, messages, and codes. Domination simply needs the foundation of the way of life as normal and expected, the naming of the dominated with the dominators, and the insidious institution of the fashionable ideology as normal and inevitable. Gramsci asserts, "a social group has to exercise leadership before it attains power, but even when it won the debate, and it must go on to run as well" (Ibid 156). As domination reaches the internal cosmos of the individuals, resistance is often impossible.

Antonio Gramsci manifests that culture is created through consent and coercion. Gramsci expresses consent as the manner in which people should be engaged directly or indirectly in the ruling actions. According to Gramsci, "the spontaneous consent given by the great masses of the population to the general direction imposed on social life by the dominant fundamental group this consent is historically by the prestige (and consequent confidence) which the dominant group enjoys because of its position and function in the world of production" (Ibid: 31). The term of consent has been suggested as background or base of the right to examine political power and identity of that power. They simply approved that the force of the governor is somehow flow. This sort of social club could not remain in confront of a developing society. Masses that are subject to hegemony are scarcely aware of it; at best, they exclusively have a brooding sense of limitation and an ambiguous desire for an alternative management. According to Strinati, "people can accept the prevailing order because they are compelled to do so by devoting their time to making a livelihood, or because they cannot conceive another way of organizing society, and therefore fatalistically accept the world as it is" (174).

Gramsci believes that the consent mourners might be the clarification of very varied beliefs, which can be split into three divisions: first, one may admit because of the danger of the resolving powers of opposition, which may generate penal destitution, including the loss of pride or personality. Second, one consents because in response to external provocation, one may naturally expect for certain objects in certain methods. Conformity in this state is a matter of silent attendance in an organized kind of activity. The third event is attached to the term of legitimacy, with a notion that the demands for consensus are more or less explained and even out.

Another hypothesis that is explained in this paper is the role of intellectual in creating a hegemonic society. For Gramsci, intellectuals have formed the lands that have formed individuals and each grade constitutes one or more groups of intellectuals. Hence, if the lower class is applied to be succeeded in becoming hegemonic, it must also form its own intellectuals to spread out a new notion. The universe of intellectual cannot exclusively increase the degree of lower stratum, but the invention and innovation are more important to expand the eternity of them. Intellectual can from the life of lower scores through the creation of new estimates regarding the escalation of aristocracy.

Subsequently, intellectuals may participate in the more general administrative organizations, which combine the economic activities with those of society as a whole. Gramsci asserts, "by intellectuals must be understood not those strata commonly which are to describe this term, but in general the entire social stratum which exercises an organizational role in the wider sense, whether in the sphere of production, or in that of culture, or in that of political administration emerging forms of opinion" (qtd. in Jones 97).

Gramsci defines two kinds of intellectuals: traditional intellectual, and organic intellectual. The initiative is called traditional intellectuals. Gramsci states that the traditional intellectual is inspired from ruling elite for achieving conformity between government and society. They are direct agents of the ruling classes, who implement lower class functions of social hegemony and political dominance. Gramsci asserts that journalists, thinkers, and broadcasters 
may still believe that they are best intellectuals. However, in the modern world, instructive education approximately bound to industrial work even at the most archaic and incompetent level must organize the creation of the new sort of intellect. This exists behind his difference between rural and urban intellectuals. Gramsci urges the traditional intellectual as, "the traditional character of intellect: the literary man, the philosopher, the poet [...] the journalist who considers himself to be a literary man, and philosopher and poet believe to be the true intellectuals" (1971: 94).

Gramsci declares the organic intellectuals have been more directly connected with the dominant phase of output. Gramsci argues, "every social group, coming into existence creates together with itself, organically, one or more strata of intellectuals" (Ibid 5). While some organic intellectuals, such as the industry specialists present services for capitalist within the generator frame, and in this regard their actions make it within the land of what Gramsci terms the economic and material demands of the capitalist class, this class must at the same time choose other intellectuals with the power to be a creator of society in general. They belong to the same historical time as a young group, which constitutes and manipulates them and these intellectuals exercise a peculiar part in all fields of social actuality.

Gramsci concentrates on words as a political matter, such as, to government policy around language, instructive words, and everyday language practices. Language spreads extensively, not by ability or state coercion, ruler or police action, but by speakers understanding the value and benefit of new languages, sentences, or terms. However, the thought that people have generally freely selected over the language they apply, the word people speak, is clearly misleading word or method to access their favorable effects. Gramsci argues:

«That not even a national language can be created artificially, by order of the state; that the Italian language was being formed itself and would be formed only in so far as the shared life of the nation gave rise to numerous and stable contacts between various parts of the nations; that the spread of a particular language is the productive activity of the writings, trade and commerce of the people who speak that particular language» (Ives 57).

Sometimes this means expressing difference, understanding with the listener. This is especially common, on differences in them. Gramsci declares constitution of language as an organized language for people by which the government keeps superiority and domination over ruled classes. Thus, the use of speech and its distribution among people served as a political dynamic for Gramsci. On that point are unlimited numbers of varied languages, which reduce the ability to transmit.

\section{Cultural Hegemony of $A$ Tale of Two Cities' Characters}

Gramsci clarifies:
"At all events, the fact that the state/government, conceived as an autonomous force, should reflect back its prestige upon the class upon which it is based, is of the greatest practical and theoretical importance, and deserves to be analyzed fully if one wants a more realistic concept of the state itself» (1971:545).

This predomination must have coherent economic backgrounds, meaning that if hegemony is artistic, religious, and educational it should have economic bases. Ruling class, including Manette who is really weakened by the murderous action of Marquis and French aristocrats, has insulted some characters in A Tale of Two Cities. Bloom describes Manette as:

«When we consider Dr. Manette's conduct, however, we find that, whether Dickens consciously intended it to be or not, the doctor of Beauvais is a good psychiatrist, at least in the handling of his own illness. His shoemaking is superficially pictured as a symptom of mental regression and decay, but in its inception, it must have been a sign of rebellion against madness rather than a symptom thereof. Shoemaking, truly an example of vocational therapy, was the only contact with reality that his distracted mind, otherwise cut from reality, possessed» (91).

Charles Dickens describes the trial of Darnay as a very sensitive moment for him and viewers in the court:

«Silence in the court! Charles Darnay had yesterday pleaded Not Guilty to an indictment denouncing him (with infinite jingle and jangle) for that he was a false traitor to our serene, illustrious, excellent, and so forth, prince, our Lord the King, by reason of his having, on divers occasions, and by divers means and ways, assisted Lewis, the French King, in his wars against our said serene, illustrious, excellent, and so forth» (Jones 80).

Gramsci expresses that the governing class was able to spread its beliefs in institutions, schools, and popular culture, which implied that the coercion was only one dimension of domination, the other being consensus, or leadership, which invariably goes to some phase of spontaneous interests. While Gramsci still searched the invention of a proletarian hegemony, he advertised a new sense for understanding existing hegemony.

In A Tale of Two Cities Sydney Carton is under the domination of Stryver who is constantly about to despise him. Carton's nickname is jackal which insults him in the face of other, Stryver is called as a lion. Stryver sees himself as a lion and Carton as the jackal. Bloom describes Carton as, "he may be a jackal, but not by choice. He is a man of good abilities and good emotions, but incapable of his own help and his own happiness" (107). In short, he is not naturally a jackal; instead of the London and Paris mob, he is not nourished by vengeance and slaughter. Stryver works scarce and walks honorably in the sunlight, while Carton quickly traces scraps at night. Though certainly more intelligent than Stryver, Carton requires social beauties and the taste of victory, and will never match Stryver's achievement.

The climax of domination of aristocracy appears among St. Evremonde family and particularly Marquis, who supposes cruelty as fantasy. His class is stupid and all the people are naught to him. Marquis runs over a kid and kills 
him by a carriage horribly, but he does not care about what was going on and get a funny looking to commoners around children. Then Evremonde believes, "repression is the only lasting philosophy. The dark deference of fear and slavery, my friend, observed the Marquis, will prevent the dogs obedient to the whip, as long as this roof, facing up to it, shuts out the sky" (Dickens 142).

Gramsci expresses that the individuals voluntarily consent to a social system that makes them alienated and weakened. He also stressed that the role-plays a noteworthy part in saving this consent. At the same time, he was mistaken that a specific class of the middle class created hegemony. Gramsci's work can substitute the hegemony of a year with the hegemony of a dominant group, and, by discussing that the current hegemony is more cultivated, decentralized, and stronger than domination by a ruling group. This text file is issued because it keeps people cautious against the hegemonic systems in the present lawful system that prevent alternative classifications that might put up an intimate appropriate with collective obligations to liberalism, justice, health.

However, the Charles's trial in England was mistaken; the French court is shown every bit even more disastrous, a general theme of justice. The reported text of the opening indictment's insolent pre-judgment of Darnay (according to the original transcript of the De La Motte trial) is lent pace and play through its pressure of the opening mission, as Charles Dickens describes the trial of Darnay as a very tender moment for him and observers in the courtyard, "silence in the courtroom! Charles Darnay had yesterday pleaded not guilty to an indictment denouncing him (with infinite jingle and jangle) for that he was a false traitor to our serene, illustrious, excellent, and so forth" (qtd. in Jones 80).

The intellectuals intend to make the social hegemony of a year, their domination is as the conformity in the generative world, and their instrument for those classes is consent whether actively or inactively. Distribution of intellectuals and developing ideologies across groups in the community has the expressed goal of changing a society's culture. The thought continues, then, that the change in culture will cause a transformation in rules and leadership, with those in power subjected to others that interest dominance. Gramsci tried to constitute intellectuals organic to the lower class by a number of the usual instruments. His involvement is not briefly to generate philosopher; he looked to increase the consciousness of all lower strata.

In A Tale of Two Cities, Stryver tries to be dominated in the cosmos. He is regardless of sacrifice for the others and only sees himself. Carton interestingly makes himself a servant to Stryver. He is sacrificing his existence for no reason, which is a case of self-murder. This exchange establishes a distinctive part of Carton's personality. He always sacrifices for others, never searching the authentic, as Stryver would. Because you know, Sydney, said Mr. Stryver, looking at him with piercing eyes and say, "do you know, I rather believed, at the time, that you sympathized with the gold-haired wench, and were ready to determine what happed to the gold-haired doll?"' (Dickens 104).

Gramsci concentrates on words that are constituted with powers. Gramsci's thoughts have been efficient to analyze how power operates within these societies. His belief of hegemony implies some of the phenomena that the term of ideology describes but adds to ideology a concentration on institutions and actions as well as beliefs and ideological systems. Gramsci continues in elaborating his belief of language, which in language, at that place is a particular assumption of the cosmos. Elsewhere he repeats this matter, emphasizing how approximately language is close to understanding and thinking, including how the shortage of language and hegemony, and cognition of particular languages is limited.

\section{Conclusion}

Gramsci considers the constitution of common people through political and cultural instruments, as though they are under control or pressure of hegemonic forces, whether by coercion or consensus. The rulers use consensus models rather than exert coercion and punishment to achieve their favorable goals. Gramsci also states the inseparability of coercion and consent. The recommended methods for governors to dominate over lower classes are education and make a unified language; then, constitution of intellectual man among different institutions.

Most of the novel's characters are virtually below the political power of aristocrats who impose their culture and beliefs to the commoners in order to keep their aristocracy. Stryver tries to dominate in the world. He is careless of sacrifice because he is very a selfish man. Carton interestingly makes himself a servant to Stryver.

\section{References}

[1] Bloom, Harold. Charles Dickens's A Tale of Two Cities. London: Chelsea House, 2007.

[2] Dailey, Donna. Charles Dickens. London: Chelsea House, 2005.

[3] Dickens, Charles. A Tale of Two Cities. New York: Michigan UP, 1859.

[4] Fontana, Benedetto. Hegemony and Power: On the Relation between Gramsci and Machiavelli. Minneapolis: Minnesota UP, 1993.

[5] Gramsci, Antonio. Selections from the Prison Note Books.Ed.and Trans. Quintin Hoare and Goffrey Nowell Smith. Lawrence and Wishart, London, 1971.

[6] --------. Selections from Cultural Writings. Cambridge: Harvard UP, 1985.

[7] Ives, Peter. Language and Hegemony in Gramsci. London: Pluto Press, 2004.

[8] Jones, Colin et al. Charles Dickens's A Tale of Two Cities and French Revolution: London: Palgrave Macmillan, 1988. 
[9] Jones, Steve. Antonio Gramsci. London and New York: Rutledge, 2006.
[10] Strinati, Dominic. An Introduction to Theories of Popular Culture. London: Routledge, 1995. 